\title{
Iceni to iconic: Literary, political and ideological transformations of Boudica through time
}

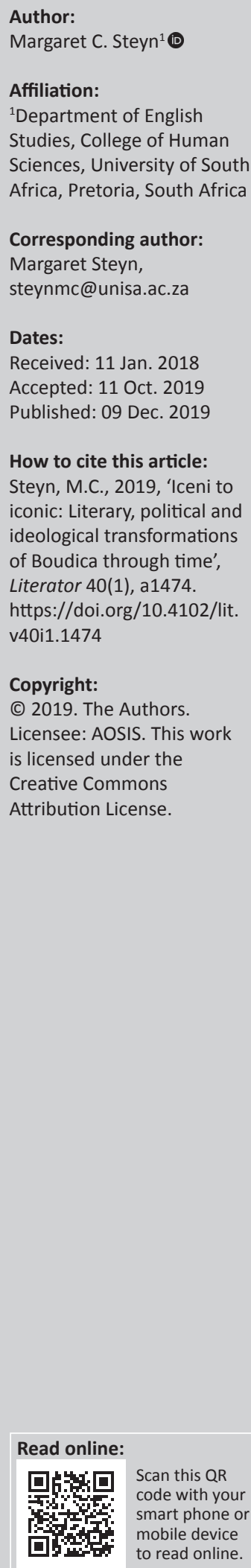

Boudica has captivated the imagination of generations of scholars, artists, writers and poets, eventually becoming firmly entrenched in popular culture which has attempted to articulate England's national identity through the dwelling on the heroic past and emphasising her position as a Muse. This article focuses on the use and manipulation of the image of Boudica to evoke the heritage of the 'noble savage' or as an example of 'native barbarianism' by successive regimes striving to establish a historical foundational past in an attempt to create a nationalist historiography. The representation of the image of Boudica through a detailed historical analysis, starting from the earliest mention in Tacitus to more recent representations of the icon, will illustrate how the dichotomy of interpretation has rendered her a chameleon: sometimes a villain and sometimes a heroine. However, through all these incarnations, Boudica never truly loses her place as a nationalistic icon, symbol of victory and figurehead of resistance for the emergent British people.

Keywords: Boudica; iconic representation; national identity; gender in antiquity; transformations of Boudica; Boudica in literature; British identity; popularisation of ancient icons; reception

\section{Introduction}

In $60 / 61 \mathrm{CE}^{1,2}$ on the eastern side of Roman Britain a series of events were set in motion that resulted in the virtually unknown widow of a minor client ruler becoming such a celebrity that she now ranks amongst the greatest names in history. Flexibility of imagination accompanies the account of the now iconic Queen of the Iceni, Boudica, who has become the epitome and embodiment of the spirit of the British people, their resistance to oppression, tenacity of fighting spirit, love of independence and unwillingness to bend before many a determined and powerful aggressor, as reflected in their ability to resist invaders after the arrival of the Normans in 1066 to Hitler's determined force during the Second World War. This article will focus on the varying interpretations of Boudica, who at different times, according to the attitudes prevalent at the time and the gender of the reigning monarch, has exemplified either the negative or the positive attitudes required from a national icon. I will suggest that social, religious and political representations of Boudica were reprocessed for public absorption, usually through the medium of state ideology. Through a discussion of this ideology it will be seen that she moved from parallel to even fictitious scenarios as her protean nature survived the twists and turns of history. The changes apparent in the representation of Boudica would indicate that she is a malleable construct within a fleshed-out narrative rather than a historical figure. It is because of this malleability that her representation can be seen to have changed so much through the ages that she has become nearly unrecognisable. My article builds on the work of Samantha Frénée-Hutchins $(2009,2016)$ and Vanessa Collingridge ([2006]2012) in looking at the ideological representation and construction of the myth and figuration of Boudica. However, I approach the myth of Boudica from a slightly different perspective, starting from what I consider to be the origin of her misrepresentation. So, I return to the Roman writers of antiquity who used the figure of Boudica for political purposes rather than for her historical value. I then trace this form of ideological manipulation through the Renaissance and into the Victorian period.

Various ephemeral representations of Boudica stood out and diminished equally as rapidly when doubt set in as to the authenticity of this 'heroine' and the fascination and problematic association of a woman with war. Nevertheless, it is safer to say that she captivated the imagination of generations of scholars, artists, writers and poets, eventually becoming firmly entrenched in popular culture. According to Barthes (2013):

1.Tacitus (Ann. 14.29-39) sets the rising in the consulship of Lucius Junius Caesennius Paetus and Publius Petronius Turpilianus which was in $61 \mathrm{CE}$. In reality, this probably covers part of 2 years and that the rebellion actually began in $60 \mathrm{CE}$.

2.All dates given are $\mathrm{CE}$ unless specifically stated otherwise. 
Myth is not defined by the object of its message but by the way in which it utters this message: there are formal limits to myth, there are no substantial ones. (p. 217)

Barthes's definition can be seen in accordance with recent scholarship on the subject of mythology, where the term 'myth' is not used to represent a commonly held impression that has an inadequate factual basis, but rather a situation where the information has been selectively chosen and communicated in a way that will further disseminate, perpetuate and elaborate valued histories that function as reinforcement of specific cultural values contained in their interpretive communities. The many representations of Boudica, I argue, establish her as a mythical creation, a figure who has been adopted to utter different ideological messages in different time periods. In one representation, she is employed in nationalistic myth-making as she steps outside the constraints of 'normal' gender roles and operates within what is generally perceived as a largely masculine realm of activity including that of leadership. Employing this definition of myth will add support to my argument that representations of this Celtic heroine have undergone various imaginative incarnations, with chroniclers and commentators, from Polydor Vergil through Milton to Tennyson and many others, who were unable to resist the allure of adding their own contributions, creating both unhistorical and fictitious roles for her. ${ }^{3}$ As Lawson (2013) succinctly states:

These differing interpretations highlight the way in which biographies are transformed according to the circumstances of the time and the interests, values and projects involved, thus producing different identities for the figure in question and, by implication, of the nation itself. (pp. 101-102)

\section{Roman representations}

Boudica became Queen of the Celtic Iceni tribe on the death of her husband, the Roman client-king, Prasutagus. After the ill-treatment of both herself and her two daughters at the hands of Roman soldiers on behalf of the Roman administration, Boudica led her people and thousands of Celts from other neighbouring tribes, such as the Trinovantes and the Catuvellauni, into a revolt against the occupiers in $60 / 61$. Although the rebellion had deeper underlying causes, it was the brutality with which she was treated that has often been cited as the prime motivator for the uprising. She was flogged and her daughters were raped as much as punishment for Iceni defiance as to reinforce their subordinate status and the pointlessness of resisting Roman orders through a deliberate and symbolic act (Tac. Ann. 14.31). ${ }^{4}$ This swift rebellion by Boudica and her allies reduced three sites to ashes, ${ }^{5}$ destroyed part of a Roman legion and caused the

3.Mythical objects cannot be discriminated against according to substance as, according to Barthes (2013:217), this would be 'entirely illusory'. Imagery, like myth, 'transforms history into nature' (Barthes [1973] 2013:129). Myth is discourse: Boudica as a mythological icon creates this discourse and is used and abused to suit the ideology of the time.

4.See Grant translation (1996:328). The editions consulted for this article are Gran (1996), Rives (2010) and Carey (1925). Citations in the remainder of the article are in the conventional format for classical sources.

5.Roman Colchester (Camulodunum), London (Londinium) and St Albans (Verulamium), where the archaeological evidence presents abundant traces of mayhem in the form of a clear destruction layer in each location dated to the right period (Sealey 2004:22-3). It is also unknown as to whether London or St Albans was attacked first or both were attacked at the same time. death of untold numbers ${ }^{6}$ and almost wrested Roman control of the province into the hands of a woman (Tac. Ann. 14.30). Boudica was written into being as a figure of British resistance against Roman rule firstly by Tacitus in his work Agricola and Germania, ${ }^{7}$ and then in The Annals of Imperial Rome (pp. 114-117), both some 50 years after the event. In Tacitus's work she is tinged with subversive nobility and a dangerous glamour, and wielded expertly as a tool in his cynical and penetrating critique of the values of the Roman Empire. Tacitus' version of the Boudican revolt was embellished, embroidered and gilded in Cassius Dio's Roman History in the 2nd century CE, in which he created a darkly glamorous physical description of the queen:

In stature she was very tall, in appearance most terrifying, in the glance of her eye most fierce and her voice was harsh; ${ }^{8}$ a great mass of the tawniest hair fell to her hips; around her neck was a large golden necklace; and she wore a tunic of divers colours over which a thick mantle was fastened with a brooch. This was her invariable attire. She now grasped a spear to aid her in terrifying all beholders and spoke as follows ... (Cass. Dio 62)

Both classical historians ${ }^{9}$ wrote to communicate specific ideals, messages and morals reflecting typical Roman attitudes to women in power. In the quote from Dio, Boudica is depicted as 'tall, terrifying, harsh and fierce', but these fearful aspects are offset by his representation of her as sexually attractive with her 'tawniest hair' falling to her hips. What Dio creates, whilst not an eyewitness description of the historical Boudica, despite the detail that is provided, I consider to be an image of a woman who has the attributes of a man, and her depiction is of an exceedingly powerful persona. It is this ambivalence in her portrayal which is an indication of the malleability of her image, which is supported by Hingley and Unwin's ([2005]2006:8) comment that 'Roman men who wrote the histories found the idea of female rulers outrageous but at the same time exciting'. Furthermore, Braund (1996:118) contends that queens fascinated Roman men because they represented the abuse of unfettered power ${ }^{10}$ and carried with them anxieties concerning gender and gender roles, reflecting paranoia about the idea of female

6.Tacitus claims 80000 Britons and 400 Romans were killed in the final battle alone (Tac. Ann. 14.37).

7.She is only mentioned once in Agricola where Tacitus attempts to explain the Briton's grievances (Tac. Agric. 15.2)

8.Condemnation of a female leader often included the fact that her voice is harsh or strident, an attitude that has carried on into the 20 th century, hence the remarks strident, an attitude that has carried on into the 20th century, hence the remarks made about Margaret Thatcher, prime minister of England, in the 1980s that she
'had a voice like a fishwife'. There are several examples through history that can be cited: Zenobia of Palmyra had a voice that was clear and like that of a man and the Rani of Jhansi who led a mutiny in 1857 was spoilt by the sound of her voice (Fraser 1988:60).

9.Reference to the uprising, but not to Boudica, is made in the work of Seutonius, Lives of the Caesars, where in Nero 39.1, he states ' $[t]$ wo towns of major importance were laid waste, with a great slaughter of citizens and allies'.

10.In general, this image can be seen through the representation in Roman literature of the treatment of powerful women and the subsequent attitudes expressed by Roman writers to such, for Roman writers to such, for example, as Cleopatra and Zenobia of Palmyra. Tacitus deliberately accentuated the vices of the queen of the Brigantes, Cartimandua's, portraying her as 'shress neglected to address why she was represented in this manner. By omitting this information, Tacitus refused to recognise that she needed to be so in order to be a 'powerful piece on the chessboard of Roman provincial politics' (Richmond 1954:52). 
rule. ${ }^{11}$ Therefore, Boudica's usurpation of imperium became a threat to the legitimacy and masculinity of those in power. Tacitus viewed women with any power as 'unduly and inappropriately' obsessed with it (Santoro L'Hoir 1994:5). In Agricola 16.1, the ablative phrase femina duce implies that imperium normally exercised by a man is misplaced in a woman's hands. Repetition of femina duce allows Tacitus to discredit the revolt by insinuating that males who tolerate a dux femina must be devoid of masculinity (Santoro L'Hoir 1994:7). ${ }^{12}$ Certainly Celtic and Germanic women had the benefit of a high degree of freedom that scandalised the Romans whose statute law ${ }^{13}$ was more misogynistic than the customary law of the tribal groups the Romans overcame (Masson 2002:56-59).

In their short descriptions, both Dio and Tacitus make mention of the 'masculinist principle of gender hierarchy', with Tacitus pointing out the peculiarity of the Britons in that they made no distinction of sex in government ${ }^{14}$ and Dio stating that wives were held in common (Mikalachki 1998:11). ${ }^{15}$ Through the pen of Dio in particular, Boudica becomes 'a caricature [of] the foreign and barbarian queen, threatening the properly male imperium of Rome' (Black 2001:421). ${ }^{16}$ Furthermore, the appearance of female leaders confirmed them in the eyes of the Romans as uncivilised primitives. The concept of gender also arises when sexual imagery is used to delineate the proximity of women to what is universally conceived to be a male arena, warfare, where the 'warrior' is very much a masculine ideal embedded in varying cultural contexts. There remain mixed feelings about connecting women with warfare and despite the fact that they often participate on equal terms this is an issue and is represented in the literary texts not openly but through the use of imagery, symbol and ritual (MacDonald 1988:2). I would suggest that it is the association of Boudica with war which is both fascinating and problematic for those who wrote about her. ${ }^{17}$

11. Semiramis is an archetypal queen for the Romans, one who was said to have not only indulged in luxury but had a sexual lifestyle that was alien and inimical to only indulged in luxury but had a sexual ifestyle that was alien and inimical to Roman conceptions of the proper behaviour for a decent woman. Cicero uses her name as an insult towards Gabinius, a R diutius est Semiramis illa retinenda? [But as for Syria, is that Semiramis any longe to be retained there?] (Cic. Prov. 4.9).

12.A full analysis of Tacitus' opinion of powerful women can be found in Tacitus and Women's Usurpation of Power by Santoro L'Hoir.

13.Caesar relates that upon marriage, the husband added the same amount to the dowry as the wife bought into the marriage. This amount is kept separate and 'profits laid by', and whoever survives the marriage retains the whole amount (Caes. BGall. 6.19). It was this ability to own property that separated Celtic women from other women at that time, as neither Greek nor Roman women could inherit property. In this case, Prastugas leaves his property to his daughters, something unheard of this case, Prastugas leaves his property to his daughters, something unheard of
under Roman paterfamilias, where the paterfamilias was the oldest living male in a household who exercised autocratic authority over his extended family.

14.'Boudicca ... We British are used to woman commanders in war', Boudica's speech in Tac. Ann. 14.34. 'Rousing each other by this and like language, under the leadership of Boudica, a woman of kingly descent (for they admit no distinction of sex in their royal successions)' Tac. Agr. 16.2-3. Actual evidence for female rule is relatively sparse and Tacitus may well have intended his remark to be restricted to a war scenario only as he offers no explanation for her role and the fact that Seutonius triumphed.

15.'Britons, men that know not how to till the soil or ply a trade, but are thoroughly versed in the art of war and hold all things in common, even children and wives', Boudica's speech in Cass. Dio 62.6.

16.The negative treatment and reaction to female rule is a phenomenon common to many societies. Fraser (1988:6-7) indicates that such a figure may be 'accompanied by disgust and fear at her very existence, emotions which would never be aroused by a male leader occupying the same position'.

17.A similar transgressor to this was Jeanne D'Arc: the Maid of Orleans.

\section{Medieval Boudica}

Yet despite being vividly yet briefly described by these two authors from antiquity, Boudica fades and disappears from written English historiography for the next 1000 years, ${ }^{18}$ meriting only the briefest of possible mentions in the mid-6th century work De Excidio et Conquestu Britanniae [On the Ruin and Conquest of Britain] by the British monk Gildas (c.500-570). ${ }^{19}$ In this work, Gildas writes the following:

Immediately on their return to Rome, owing to deficiency, as they said, of necessaries provided by the land, and with no suspicion of rebellion, the treacherous lioness killed the rulers who had been left behind ... They present their backs, instead of their shields, to the pursuers, their necks to the sword, while a chilling terror ran through their bones: they hold forth their hands to be bound like women; so that it was spread far and wide as a proverb and a derision: the Britons are neither brave in war nor in peace faithful. (De Excidio Britanniae 1.6) ${ }^{20}$

This interpretation, which can be hotly disputed, has been seen by some scholars as the author's referring to Boudica as a 'treacherous lioness', which I would relate to the image evoked by Dio of Boudica's 'tawniest hair' and her 'eye most fierce'. Her representation is anthropomorphised by Gildas, but still possesses the terror associated with her in Dio. Gildas' words have been frequently understood as referring to Boudica's revolt against Suetonius Paulinus, when the latter was in Anglesey in 62 CE. Opinion is that the words may imply an allusion to that vassal queen. How reputable Gildas was, should be taken under consideration, as a 6thcentury monk, his unequivocal words, 'the general destruction of every-thing that is good, and the general growth of evil throughout the land' (De Excidio Britanniae 1.1), are indicative of his dislike of Boudica's rebellion against Rome. If his description is of Boudica, I would argue this ideologically situates her in a very unfavourable manner as an ungrateful and underhanded savage. However, Gildas also had a tendency to refer not only to people but also to countries as lionesses; in chapter 23, leaena barbara stands for the home of the Saxon hordes, and in chapter 27, for the kingdom of Damnonia. Given this line of reasoning, he may well have been referring to England the country (Thompson 1979:204) and not making some oblique reference to Boudica, in which case she disappears into total obscurity once more, and the great champion of British resistance against Rome is forgotten.

This fall into obscurity is perpetuated in the work of the Northumbian monk Venerable Bede, Historia Ecclesiastica gentis Anglorum [Ecclesiastical History of the English People] in 731, where she goes entirely unmentioned despite his acknowledgement of the Claudian invasion. ${ }^{21}$ Similarly, she

18.It is because so little is actually known about her life that the legends and interpretations have been able to flourish; her life is, in Umberto Eco's words, an 'open text', one that is endlessly interpretable (Jeffries 2004).

19.Gildas was a monk or cleric whose work is difficult to date; consensus is that it is from the mid-5th or 6th century. Further, the name Gildas is now considered to be a pseudonym (Williams 2009:38).

20.Translated from the Latin by Roger Pearse (2003).

21.Julius Caesar's unsuccessful invasion of Britain in 55 and 54 BCE was followed by that of Emperor Claudius in 43 CE under the leadership of Aulus Plautius. Claudius fully intended to incorporate Britain into the Roman Empire, a feat which he believed would bring him military glory. 
is absent from Nennius' Historia Britonum [History of Britain] c. 760, and she and her uprising are completely omitted from Geoffrey of Monmouth's mid-12th century work, Historia Regum Britanniae [The History of the Kings of Britain]. Monmouth's work is an assemblage of ancestral national myths of origin, which are generally now dismissed as 'spurious hokum' and 'creative imagination' with very little genuine historical content (Collingridge [2006]2012:309; MacDougal 1982; Samuel 1990:120; Trow 2003:215). After all it was Geoffrey of Monmouth's work, in his attempt to legitimise the rule of Henry 1, that established the factually unsound Romanised myth of origin that Britain was founded by Brutus, a direct descendant of Aeneas soon after his escape from Troy. ${ }^{22}$ This ennobling beginning and suggestion of a common history continued to hold sway for some 400 years of British history whilst church and state were extending their grasp over the people and giving no credence to a rebellious warrior queen whose portrayal would, I suggest, have challenged the ideology and authority of legitimate government (Collingridge [2006]2012:309). It is during this time period that the figure of Boudica seems to disappear from the pages of history.

\section{Renaissance representations}

Boudica may well have faded permanently into oblivion had it not been for the Italian scholar Giovanni Boccaccio and the medieval monks of Monte Cassino who, in the 14th century, allegedly discovered a single manuscript containing books 11-16 of Tacitus' works, believed to be a first copy of the original, in their neglected library. ${ }^{23}$ The development of the printing press in 1450 then made Tacitus available to a broader society and he became required reading for anyone wishing to be considered well read in the 15th and 16th centuries (Collingridge [2006]2012:311). Similarly, it is this period that witnessed the beginning of the Tudor Dynasty in 1485 and the subsequent rise of the early modern nation state and the discourses that emerged to support it. Under the Tudors, history and popular myths to prove the monarch's noble pedigree were used to promote loyalty to the Crown and create greater internal unity, whilst under James I a stronger national and imperialist discourse emerged. Renaissance historians and scholars then took over and Boudica re-entered historiography, with a certain degree of metamorphosis. She became first one person and then another - and even became two - as she evolved with the social, political and legal fluctuations in the status of women, giving us an early example of what we now label as misogyny. Mikalachki (1998:13) is clear that this is the point when native origins of England were to be understood entirely in terms of female excess, '[s]avage, rebellious and self-destructive, ancient Britain as a whole became analogous ... to early

22. Thus, when the Normans, i.e. Bretons, arrived in England in 1066 they were simply reclaiming the land of their ancestors' (Frenee-Hutchins 2009:104).

23.The text was believed to have been transcribed in the mid-11th century CE. The first six books of his Annals were later discovered at Corvey Abbey in Germany by Enoch of Ascoli who obtained them in 1455. Conversely, Dio's account of Roman events covering the period $47-235$ CE only became available, as an epitome, in 1548 with the publication of the monk Xiphilinus' Epitomes, obtained from a manuscript held in the publication of the monk Xiphilinus' Epitomes, obtained from a manuscript
the French king's library in Fontainebleau (Bouillet \& Chassang 1878:2023). modern constructions of insubordinate womanhood'. Thus, these Renaissance representations of Boudica are ideologically motivated to show what happens when a woman is allowed to assume any form of power. It was Polydore Vergil ${ }^{24}$ the deputy collector of St Peter's Pence, who arrived in England from Rome in 1501 and began his Historiae Anglicae Libri in 1506, published in 1534, who reintroduced Boudica to the English people through his culling of information from both of Tacitus' works The Agricola and The Annales but ignoring Dio's. ${ }^{25}$ Utilising two differing names, he created two women of diverse temperaments: Voadicca, a queen from the north, and Bonduca, a wild and savage warrior, capable of gruesome acts in her pursuit of freedom from the Romans. This error was to be compounded throughout several generations as his work was slavishly copied. His work created a spatial and geographic splitting of the figure of Boudica where she becomes both a queen and a savage warrior and in this manner he establishes two 'different' women, which disperses the strength of the original representations of her by Dio and Tacitus. ${ }^{26}$

Boudica's re-invention is also apparent in the Scottish historian and humanist Hector Boece's ${ }^{27}$ work, the Historia Gentis Scotorum [History of Scotland] of 1527, a relatively inaccurate but certainly patriotic piece that was well received. Here Boece relocated Boudica to northern Britain, transforming her into 'Voada', a sister of the Scottish kings Caratak and Corbrede [Corbreid], and married to 'Arvisagus' ${ }^{28}$ In this new version of events, she retained her original two daughters but also gained a son. ${ }^{29}$ As Johnson (2012:112) indicates, she is now situated safely within a domestic and familial unit, she is a woman before she is a heroine, a wife and mother before she is a lioness. She is shown as a member of the Scottish royal family leading a force comprised of 5000 of the good ladies of Scotland to war and battle, fighting as a woman on behalf of women, all the time stressing national identity and the concept of nationhood, along with the need to overcome the Roman invaders. Boece used the relocation of Boudica to Scotland, according to Hingley and Unwin ([2005]2006:117), to expose the part played by Scotland against the Romans at the time, ${ }^{30}$ all the while playing up the importance of Scotland. Even whilst being located within the domestic unit, Voada remains a warrior and

24.Perhaps he could have been considered as the spiritual successor of Catus Decianus, the original procurator blamed for the uprising with his ruthless and inhumane tax collecting (Trow 2003:215).

25.Dudley and Webster (1962:116) state that it is believed that Vergil used Dio's text as his source, hence the two names, yet Vergil categorically states that he used Tacitus.

26.It was Vergil's work that first cast doubt on the historical authenticity of Geoffrey of Monmouth's spurious claims.

27. Several scholars believe that Boece drew on Tacitus' work and embellished it with indigenous narrative (Collingridge 2006:313). Frenee-Hutchins (2016:24) indicates that Boece may have used sources other than Tacitus that Polydore Vergil did not know of or have access to.

28.In reality, Arvisagus was the chief and eponym of Dalriata in 220 (Dudley \& Webster 1962:11).

29.It is believed that Arvisagus has been confused with Caratacus, who along with his brother Togdomnus led the initial resistance to the Romans in $43 \mathrm{CE}$. It appears that Boudica is being conflated with Queen Cartimandua of the Brigantes who betrayed Caracatus (Dudley \& Webster 1962:117).

30.During the Roman occupation of Britain, Scotland, known then as Caledonia, was considered a wilder place and was controlled by several fierce warrior tribes. Ultimately both the Emperors Hadrian and Antoninus had walls constructed to protect themselves from raiding by these northern tribes. 
retains the ambiguous nature that is a feature of the representations of Boudica. In this work, gender is important and is brought to bear as it is Voada's stirring speech and her formulation of a fighting unit that will avenge the dishonour and rapes committed against her family (MacDonald 1988):

I shall not lack men's hardiness, but I shall fight foremost in the brunt, where most danger appears, with five thousand ladies, who are all sworn to avenge the cruelties done by the Romans ... I can have no mercy on them. (p. 47)

This oratory, which is considered a necessary skill for a leader addressing troops, can be likened to Elizabeth I's famous Tilbury speech: 'I know I have the body of a weak and feeble woman, but I have the heart and stomach of a king' (Neale 1957:309). Certainly these public speeches from both illustrate their right and abilities to address their troops as martial leaders. Boudica, as the figure of Voada, is again associated with militarism and male aggressivity coincident with mercilessness to an enemy.

Raphael Holinshed was the next historical writer to further embellish the Boudica story. His contribution, the Chronicles of England, Scotland and Ireland ${ }^{31}$ first in 1577 and again in 1587, perpetuated the Vergil/Boece myths with the fleshing out of a fabricated family biography, although he at least situated Boudica and the rebellion in the correct geographical location. In Holinshed's work, the rebellion takes on an even more female nature; there is an all-female family cast. Boudica is still Voada, but this is now also the name of her eldest daughter, who coincidentally marries a Roman nobleman named Marius. It is the youngest daughter, Voadicca, who becomes the proverbial thorn in the Roman flesh, engaging them on the Isle of Man before finally being killed whilst fighting the Romans in Ireland. The ideological construction present in this work is one that emphasises the resistance to masculine Rome as having been purely female, from the family to female warriors to female deities. Despite being written in the Elizabethan era, a narrow line had to be followed between creating literary comparisons between the two queens, Voada and the Virgin ${ }^{32}$ Queen through the reconciliation of Elizabeth I's image with that of a historical British queen who was bloodthirsty and savage.

Thus, Holinshed drew clear feminine and masculine distinctions throughout his work and reiterated ancient Roman ideals of gender politics, the Romans: emperor, troops and commanding officers are all male, disciplined and stoic, whilst the British man suffers the ignominy of being compared to a woman with regard to his military prowess. Boudica herself represents a form of total female excess as she utters promises of victory through oratory and prayer to the goddess Adraste, all the while exhorting her predominantly female army into battle: 'I give thee thanks O Adraste, and call upon thee thou woman of women, ...

31.These are now known as Holinshed's Chronicles and had 11 other contributors in addition to Holinshed himself.

32.This was another of Elizabeth's metaphors as she appropriated symbols of the Virgin Mary in order to present her own religious ideology, an improvisation of power. Elizabeth's own sense of self-presentation tended more towards divine protection than that of martial impulsivity. whereby the women have the like audacity with the men, and no less boldness in the war than they'. (Matza 2010:66). Rather than native resistance to Roman domination this becomes an illustration of gender, with the masculine hierarchy resting firmly with the more civilised Roman oppressor: '[s]uch forwardness in the soldiers followed upon this exhortation of the courageous general, that very one prepared himself so readily to do his duty, and that with such a show of skill and experience'. (Matza 2010:70). Holinshed is clear in his condemnation of the savage female-directed atrocities and violence of the British troops and their lack of discipline whilst under Boudica's woman-led command, which is described in some lurid detail: '[f]or there was nothing with the Britains but slaughter, fire, gallows, and such like, so earnest were they set on revenge. They spare neither age nor sex'. (Matza 2010:68) Her defeat is the inevitable result of the inability of a woman to exercise sovereignty without the discipline and intervention of masculine order and civility (Mikalachki 1998:13). Female rule and barbarity are grotesquely clamped together in this ideological representation of Boudica as an incompetent and ill-disciplined leader who lacks male restraint and stoicism. ${ }^{33}$ The didactic purpose of this writing is clear and is stated by Holinshed himself where he indicates that history is important and should be taught by example.

The lesser known Italian writer Petruccio Ulbadini (15241600) in his work Le vite delle donne illustri, del regno d'Inghilterra, e del regno di scotia [The Lives of the Noble Ladies of the Kingdom of England and Scotland] in the late 1500s, also utilises two personas for Boudica in a construction that Hingley and Unwin ([2005]2006:123) feel was used to avoid the dilemma of the contradictory elements of the positive and negative versions of the story presented, through the medium of a single persona, in Tacitus and Dio. This work by Ulbadini was presented to Queen Elizabeth I during his career in England and the description of the Boudica figure is a reflection of Elizabeth's stature in that: 'Voadicia left such a strong mark in the memory of the people because she was commemorated amongst the great women of this kingdom for her marvellous virtues' (Ubaldini quoted in Hingley \& Unwin [2005]2006:123). As a result, we are given the virtuous, honourable and noble Voadicia, which is contrasted with Ulbadini's evocation of the figure of the savage and cruel Bunduica (Hingley \& Unwin [2005]2006:212). The dilemma of presenting a ruler exhibiting such savage brutality is neatly resolved by the creation of two characters, the 'good' queen taken from Tacitus and the 'bad' queen from $\mathrm{Dio}^{34}$ reinforced

33. Holinshed's work, considered a substantial history of the British Isles, frequently served as a source for Shakespeare's plays, including King Lear and Cymbeline, both of which reflect some concerns on the theme of unruly women 'Now, all the plagues that in the pendulous air/Hang fated o'er men's faults light on thy daughters!' (Lear 3.4.7); 'Property deformity shows not in the fiend/So horrid as in women' (Lear 4.2.59-60).

In Cymbeline, there is the unnamed 'wicked queen' (5.5.464) who, according to Williams (2009:43), 'bears a striking resemblance to Boudica in her rabidly antiRoman politics'.

34.Frenee-Hutchins (2016:27) emphasises that it was with the appearance of Dio's text that the revolt was given a religious and theatrical dimension and Boudica was depicted as barbaric and cruel. It was this complete dichotomy to the representation of Tacitus in which she was the military leader defending her people and a 'victim' distanced from any atrocities committed by her followers that necessitated the distanced from any atro
splits under Elizabeth. 
by Boece. Ulbadini's work, I would argue, reflects the division of Boudica found in both the works of Boece and Holinshed but continues to perpetuate an ideological stance that associates women with either savagery and cruelty or virtuousness and nobility. The analogy between Voadicia and Elizabeth rests on the idea of the marvellous virtues of the Virgin Queen, as opposed to glorifying the martial aspects of powerful women. ${ }^{35}$

\section{Elizabethan adoption}

By 1591, under Elizabeth I the Annals and Agricola made their appearance in English, translated by her Latin secretary, Sir Henry Savile. The legend of Boudica took off on a political and social trajectory - for the first time she was annexed by a society for its own purposes as if the problem of a powerful woman in a patriarchal society could be dealt with through an intermediary from the past (MacDonald 1988:48). At the time of Savile's translation, England was still revelling in its success against the Spanish Armada where Elizabeth had made an impressive appearance at Tilbury, riding a white horse, wearing a breastplate with her red hair loose, exhorting her troops and promising unification and victory against the foreign threat whilst appearing almost as a reincarnation of Boudica in her chariot prior to the final battle. ${ }^{36}$ The analogy of image is clear, this is a military leader defending her people although Elizabeth is presented as more constrained than Boudica as she effectively delegates command of her troops and is not reflected as participating in the public military arena, thus reinforcing the ideology that Elizabeth was silent and chaste and removed from barbaric savagery, something that reflected native origins.

Through the medium of reported 'patriotic speeches', both women became mouthpieces that stressed their female courage, an effective strategy which defeminised the male enemy, all the while representing themselves as honorary men who were descendants of those 'mighty men' (Tac. Ann. 14.34) of the past. The rhetorical formatting of these speeches was highly effective in rousing emotion, bravura and a sense of outraged dignity. This use of a sense of outraged dignity facilitated the unification of their forces against their respective common enemies (Frenee-Hutchins 2009:116). An era of growing enquiries into English identity and attempts to establish national origins encouraged a connection with a powerful female leader against a foreign invader and so Elizabeth I and Boudica, I would suggest, became conflated. Each reinforced the other's public image and this placed Elizabeth within a reassuring historical tradition, whilst at the same time assisting the queen of England in shaping her own religious and military position. This further created a

35.To represent Elizabeth as a woman warrior while she was alive was a delicate proposition' (Walker 2004:40).

36.It has even been suggested that the classically educated Elizabeth borrowed from the words attributed to Boudica by Tacitus in making her own speech at Tilbury (Hingley \& Unwin 2006:119).

The The poet Jonathan Aske, who witnessed the event, also saw a resemblance and felt that both Penthesilea and Boudica were seen to live again's through the person of 158, ho Tiloury. In his triumphant ode on the Elizabeth's defeat of the Spanish in 1588, he proclaimed Elizabeth as 'Voada, once England's happie queene ....
through this our Queene, now England's happy Queene' in his Elizabetha Triumphans (Aske 1588:line 786) strong public image of Elizabeth that would counter the previously violent, excessive and negative role model for women that had been created by her older sister, Mary I, whose religion and marriage were a betrayal of the ideology associated with England and being English. ${ }^{37}$ Representations of Boudica and the misapprehensions surrounding her story have to be set within the framework of a developing consciousness of the nation and of the self. England under the rule of Elizabeth I saw a more self-confident and selfconscious attempt at national identity based on political, religious and cultural unity. The period has been referred to as one of 'self-fashioning' by Stephen Greenblatt (1980), an expression which defines the process by which men and women, as subjects of a state, construct their public and social identities, including class allegiance and gender roles, according to the social and political values of the early modern period.

The playwrights of the Elizabethan era, discouraged from dramatizing religion due to growing discord and religious tension, were rather encouraged to feature mythological, historical, allegorical and heroic tales in their works (Collingridge [2006]2012:312). The Privy Council itself encouraged and actually rewarded those representations of the queen in all areas, including the arts. Elizabeth promoted courtly plays, epic poems and masque balls about great women from history and so Boudica, as the prototypical Amazonian 'female worthy' (Wright 1946:628), was ranked alongside her contemporary Cartimandua ${ }^{38}$ a variety of biblical characters such as the judge and prophetess Deborah, the heroine Jael from the Book of Judges, and more mythical warrior queens from classical literature such as Pentheselia ${ }^{39}$ and her tribe of Amazons. ${ }^{40}$ Their images were used to buttress or justify the idea of female rule, and through this the message was clear: women could and did rule over men (Collingridge [2006]2012:312). During the reign of Elizabeth, the story of Boudica was thus re-engineered to accommodate facets of monarchy, gender, war and religion; sometimes the daughters were expunged altogether as they did not fit the comparison with the 'Virgin Queen'; in others the rape was excluded as unseemly for the audience (Collingridge [2006]2012:313). In some versions, the Roman army became the proxy for the Roman Church in a country concerned with Catholicism, tyranny and oppression, whilst in other versions Boudica actually triumphed over the oppressor. As Collingridge ([2006]2012:313) intimates, Boudica's tale became a cultural 'pick and mix' for Elizabeth's moments. MacDonald (1988:48) notes that ' $[t]$ wo of the Boadicea myths - namely, that she was queen of England, and that she was victorious - were both prevalent in literature at this time', and that other ingredients of the myth, notably Boadicea's motherhood, her daughters and the rape of her daughters,

37.Colloquially known as Bloody Mary.

38.Cartimandua was a 1st-century Celtic leader, queen of the Brigantes, territorially the biggest tribe in Britain, circa 43 to $69 \mathrm{CE}$

39.Penthesilea was an Amazonian queen in Greek mythology who assisted Troy in the Trojan War.

40.This was presented, according to Collingridge (2006), in a masque in 1579. 
were ignored in praises of the Virgin Queen. I would argue that this form of intertextuality facilitated both a looking backwards for recognition whilst, at the same time, creating meaningful connections to the present.

Elizabeth is referred to in playwright and poet Edmund Spenser's The Faerie Queene. She becomes celebrated as 'Bunduca - O famous moniment of womens prayse' (2014: II.x.56.1.1), presenting her as an example of heroism, courage and patriotism as he selectively chose only certain positive aspects of the story, omitting the negative ones. ${ }^{41}$ It is Spenser who introduces the character of Britomart who he claims is both the descendant of Boudica and thus the ancestor of Elizabeth. Through this careful manipulation of ancestry, he legitimises both a woman's ability to reign and her right as a woman to the throne of England. For his production, The Faerie Queene, a contemporary of Spenser's, Thomas Nashe, lauded him as 'the Vergil of England', in recognition of his response to the ideological needs of the Tudor family in the same manner as Vergil did for Augustus (McKerrow 1958:299). ${ }^{42}$ However, even if according to Trow (2003:219) 'Boudica's star shone only as long as Elizabeth's', but it did serve to root Boudica firmly in the public imagination, thereby ensuring that she would not again fade away from the collective memory and into obscurity. It should be noted that despite the long and successful reign of a woman and the resurrection of gynarchies such as Boudica's into the public eye, this did not mean the beginning of female liberation but rather that these few women were presented as anomalies and exceptional.

\section{Stuart misogynism}

However, the focus soon shifted and the representation of Boudica became domesticated as she reverted to a more traditional domesticated feminine role under a male monarch, James I. ${ }^{43}$ Strong female leaders were dismissed, defeminised and demonised as women were reconsigned to the home and family since James was eager to emphasise his own male identity. The monarchy was thus reclaimed for men through the work of playwrights and authors. The previous representation of Boudica as possessing positive attributes of strength and courage, I argue, was undermined and replaced with ideological pejoratives such as craftiness, petulance, mental and physical inferiority - all stereotypical and misogynistic traits applied to powerful women and recognisable from Roman literary devices. In reality, gender attitudes in Britain were very similar to those in the Roman Empire, female rulers were targets for moralising and condemnation and the savage excesses described by Tacitus

41. Hamilton (2014:256) notes that Spenser attempted to single out Boudica as a prototype for Elizabeth and further highlights the analogy that in the work Bunduca succeeds Lucius, England's first Christian King, as Elizabeth succeeds Henry VIII, the first defender of the faith.

42.According to Nashe, Chaucer is the English Homer (Frenee-Hutchins 2009:106).

43.James VI of Scotland succeeded as James I of England after the throne had been occupied for more than 50 years by women, Mary and Elizabeth. James' personal alliances with his male favourites were discussed even in international dispatches and cast aspersions on his ability to reign and caused some anxiety amongst his and cast aspersions on his ability to reign and caused some anxiety amongst his
subjects. Further into his reign there was a mounting feeling that England had inherited both a sexual and religious changeling. and Dio were then seen as the inevitable consequence of female rule ${ }^{44}$ (Hingley \& Unwin [2005]2006:115). The popular playwright John Fletcher reflected this bitter misogynistic tone ${ }^{45}$ in his work The Tragedie of Bonduca (1613) in which Caratacus (see footnote 25) reappears as the British warrior Caratach, commander of Boudica's army, and as the centre figure is the real authoritative and military power (MacDonald 1988:49). Bonduca is depicted as a cruel queen and savage mother, a reckless and incompetent leader, a cantankerous, meddling virago ${ }^{46}$ who ultimately causes Caratach to lose the war, leaving nothing but a 'wilderness of wretches' (Act III.iii) and she is seen as successfully destroying the very kingdom she had sought to save. Fletcher (1979), I suggest, reduced a potentially national heroine to one who was incompetent and boastful. This form of vitriolic belittlement can be clearly seen in the below excerpt, from Act III.v of the play:

Caratach: A Women's Wisdom in our Triumphs? Out, ye sluts, ye Follies; from our Swords Filch our Revenges basely? [he is remonstrating with the daughters who are torturing the rapists and he wants them released] Arm again, Gentlemen soldiers, I charge ye, help 'em.

Daughter 2: By--------- Uncle, we will have vengeance for our Rapes. Caratach: By ---------, you should have kept your Legs close then. (Bonduca - A Tragedy Act III.v)

Fletcher's overall attitude to women in general is shown in his ambivalent attitude to the rape of the daughters and his cruel remarks as he refers to them as 'sluts', as 'follies' or madwomen, who have stolen the male right by usurping the male right to bearing the sword and taking vengeance. His is a chauvinist cry that was to echo for centuries to come, was that 'she was asking for it'. Such a statement aligns Caratach in the play with men, the soldiers, even if they are the enemy rather than with the women. Female honour is dismissed in favour of male honour and this also ultimately overrides his loyalty to Britain. In Fletcher's play, Boudica becomes the exemplar by which it is illustrated that women in power are detrimental to society and are better employed staying in the home and following domestic activities. Boudica's rebellion can thus be interpreted as an act of female insubordination against the natural order of patriarchy (Frenee-Hutchins 2009:23). This propagandistic representation of Boudica, I suggest, is one that sets out to demonstrate that any power given to women will result in destruction and destabilisation of male hegemonic relations. Caratach refers to her only by insulting generalisations: 'woman fool' (III.v. 128), 'scurvie woman, beastly woman' (III.v.138), and later, 'O thou woman,/Thou agent for adversities' (V.i.3-4).

Shakespeare, a contemporary of and collaborator with Fletcher, further illustrates the male attitude that woman was assumed to be the guilty party - Cleopatra's selfish ways and weak romanticism distract the great Anthony from his civic duty and Lady Macbeth emotionally forces her husband to 44.This can also be seen in Lady Macbeth's cry of unsex me here (Macbeth I.v.42). 45.It should be noted that this misogynistic tone was not confined to this particular piece of work of Fletchers.

46.The term 'virago' from the Latin vir is equated with a woman with 'manly qualities' and was not always complimentary. 
commit murder to satisfy her vaulting ambition. Both these Shakespearean female characters and Fletcher's Boudica are represented as detrimental to the masculine status quo through an assumption of power, ambition and authority of which they are not worthy. It is better to admire a male enemy than to respect a woman with power. ${ }^{47}$ This gendered dynamic was a typical reflection of male-orientated Jacobean society ${ }^{48}$ which was further influenced by proclamations from the pulpit, where theatre was not considered a frivolous recreation: it served a purpose and function, being both didactic and propagandist and inappropriate for women. ${ }^{49}$ At an even deeper level, the control of women then, as in many societies now, was seen as essential to social order, and evidently Boudica was considered out of control (YuvalDavis 1993:623). All of this contributed to the threat of powerful women, as under the reign of Elizabeth and Mary and Mary, Queen of Scots, James 1's mother, theatre also assumed the role of passing moral judgement. Ideologically, it was important for James I to suppress images of a powerful warlike woman who was closely identified with British nationalism. Thus, Tragedie promotes replacement of a female warrior by a male in a similar manner to the way in which James, who was now the king, had followed Elizabeth, thus denying any doubts cast on his ability to govern. I would argue that stories of the history of Britain, and Boudica, can then be seen to be only as strong as the current ruler and their ideologies permit.

After the protracted Jacobean period and the Cromwellian (1567-1660) puritanical religious repression and civil strife, England emerged into the light in 1660 under Charles II, 'the Merry Monarch'. The theatres reopened after 18 years of silence and there was a resurgence in the arts, but although women were now permitted to perform on stage, Boudica, according to Collingridge ([2006]2012:322), still had to conform to the stereotypes and moralities of the day; the warrior queen thus became a genteel Restoration woman transported back in time. Milton (1608-1674) in the History of Britain, writing under Charles II, reflected his contempt for a nation led by women and hesitated to have Boudica speak about the beatings and the rapes as it was considered unbecoming for a woman to speak of such matters and certainly not in the company of men, 'Worthier silence, retirement and a Veil, than for a woman to repeat as done to her own person or to hear repeated before an host of men ...' (II.79). Although not as transparent or obvious, Milton is also using the 'warrior queen' to present an ideological propagandistic point of view. Milton was an ardent Puritan and Charles I, the deposed and executed monarch, was a closet Catholic. Eggert (2015:175) maintains that this creates an association of Charles with the 'feminised Christ of the Roman Catholic Passion, making him not a king at all but a queen'. Milton was the first to suggest that the speeches in

47.It is also Fletcher who is the first proponent to introduce the presence of druids into the story of Boudica. In the play, the druids, although still subdued are placed into the public imagination when in Act Three they attend a sacrifice.

48. Many of the visual representations of Jacobean society often reinforced the patriarchal order of society, where a deliberate gap is created between the father and the rest of his family, such as in the official portraits of James I.

49.Jacobite theatre was heavily censored by the Lord Chamberlain under James I. both Tacitus and Dio attributed to Boudica were in fact of their own making. He states:

I affect not set speeches in a history, unless known for certain to have been spoken in effect as they are written ... and to invent such, though eloquently (as some historians have done,) is an abuse of posterity, raising, in them that read, other conceptions of those times and persons that were true. (II.80)

Furthermore, Milton uses Boudica to cast suspicion on the veracity of Roman and Greek writers and questions their motives, all the while showing that it is the colonised who were responsible for their own difficulties:

Out of a vanity, hoping to embellish and set out this Historie with the strangeness of our manners, not caring in the mean while to brand us with the rankest note of Barbarism, as if in Britain Woemen were men and Men Woemen. (II.79)

In between his criticisms of her lack of modesty he also casts doubt on her attributed appearance and actions, rather than supporting Dio's emphasis on her warlike attributes (Hingley \& Unwin [2005]2006:136). It is these less warlike attributes that Charles Hopkins reproduced in his tragedy Boadicea, Queen of Britain (1697). Once again, the queen was not allowed to rule alone: a male figure, Cassibelan ${ }^{50}$ was the 'warrior', and Boudica, now promoted to Queen of all England, was relegated to the role of 'feisty female figurehead' (Collingridge [2006]2012:324). She was also shown to have a complicated and turbulent domestic life, rather than being involved in the real blood of conflict. Restoration theatre was not ready to present a true warrior queen; her representation was still being ideologically constructed and controlled by the social mores of the day as she was aligned with the ideals of subordinate womanhood..$^{51}$

\section{Romantic rebel}

Eighteenth-century romanticism, on the other hand, witnessed an increase in interest in Boudica; she suited British ideas of nationalism as Roman imperialism was considered as an ideal model for their expansion in the Americas. Ideas were expounded that the Romans conquering and colonising 'barbaric' Britain could be paralleled with Britain conquering and colonising 'barbaric' America. William Cowper co-opted her as the druidic princess (Bloom 2010:15), '[s]at the Druid, hoary chief ... Princess!' (Cowper 1803:II) a warrior heroine revolutionary in his 1782 poem 'Boadicea' whose actions had assisted and inspired those who stood against the American rebels. Here he inverts Boudica's role, the rebel has become the imperialist and the oppressed the oppressor; this strange relationship between growing British nationalism and the background of Roman imperialism gives strength and pride to a now united Great Britain whose empire could be judged to be more extensive than that of the Romans, effectively minimising Roman domination (Hingley 2000:73; Vance

50.Named after the historical Cassivellaunus, a British tribal chieftain who had attempted to repel Caesar and his troops during the first invasion of Britain in $54 \mathrm{BCE}$.

51.The presence of the Druids is amplified in Hopkin's play as their role is developed and they now play a major element of the story. This helps cement one of the enduring myths around the story of Boudica. 
1997:198). Bloom (2010:15) cites this as a 'perverse misreading of ancient history' in that she now came to ideologically represent a symbol of Palmerston's Pax Brittannica, a restatement of Pax Romana:

She, with all a monarch's pride

Felt them in her bosom glow:

Rushed to battle, fought and died;

Dying, hurled them at the foe. (Cowper 1803: X)

Once again Boudica is represented as martial exhibit through the words, a 'monarch's pride', and rushing into battle, she is seen to fight like a man and to die. This work was written shortly after Britain gained control over North America and during the American War of Independence. Boudica is represented as the established monarch, proud of her achievements in the new societies that Britain was creating and the new-found champion of imperialism. The Romantics of the period relished the idea of a savage and heroic Briton who could remind them of their fundamentally glorious nature. Such poetics appealed to the British love of liberty as the country was engaged in almost constant warfare for the second half of the 18th century. Boudica could stir the passions and so once again her story was manipulated and she was used as a leitmotif to suit British nationalism, as she was projected into the context of British Empire in order to complement the growing pride in British heritage and culture (Hingley \& Unwin [2005]2006:150). The supremacy of England required a celebration and development of British national identity that represented English concerns, and as one of the British ancestors, Boudica could historically secure and legitimise global claims.

I maintain that in this period she was further ideologically reshaped, this time for heroic patriotic purposes. Celebrating her Celtic heritage, Horace Walpole encapsulated all this when he wrote (Smiles 1994: 44):

Our empire is falling to pieces; we are relapsing to a little island. In that state men are apt to imagine how great their ancestors have been ... the few, that are studious, look into the memorials of past time; nations, like private person, seek lustre from their progenitors. (p. 44)

Strangely enough it is Cowper's poem that cemented Boudica's image in the minds of the British public. Hingley \& Unwin ([2005]2006:157) indicate that it was learnt by thousands of Victorian and early 20th-century schoolchildren and quoted widely in later times. This imagery placed her on the path as England's national heroine, a position that would be redefined in the late 19th and 20th centuries. However, it was David Hume (1711-1776), a contemporary of Cowper, in his History of England, who firmly placed responsibility for Boudica's rebellion in the hands of the Druids (Matza 2010:29). In Hume's work, the Druids conveniently become practitioners of black arts and Boudica is now wedded to the idea of human sacrifice, mass murder and religious terror. In this manner, I suggest that Hume effectively 'emasculates' her, whilst further blurring the lines between fact and fiction. To a degree, this can be seen as more than reshaping but rather as an act that suppressed cultural and historical reality.
Dio's account of bloodthirsty revenge sat uncomfortably with many writers and the Druids were now seen as a convenient way to shift the responsibility from Boudica as a single representative figure, and I suggest that they became scapegoats for her violent actions in a similar manner to the way in which older writers had separated her into 'good' and 'bad' personas. Furthermore, I consider it allowed her womanly side to take precedence as she could now be established at a distance from any savagery, something necessary for her to function as a patriotic example.

\section{Boudica the imperialist}

Ultimately, Boudica was only propelled into a representation of power and strength with the coming to the throne of another forceful queen. Boudica was positioned as an international icon of the British Empire, and was conflated with her alter ego Britannia, thereby irrevocably confirming her place in the national consciousness. Queen Victoria established a connection in terms of gender, behaviour as a ruling monarch, and through her seeming embrace of Boudica's earthy warrior queen characteristics. Victoria as Britannia's elite and nationalistic figurehead along with her staunch duty to family and the nation came with the recognition that there was a need for an impressive figurehead, such as Boudica-Britannia, during the period of colonial expansion (Collingridge [2006]2012:363). No longer would Britain take the role of the defeated nation, but rather one that had almost succeeded in driving the venerated Romans from the country (Collingridge [2006]2012:348). Boudica's image was revitalised and her mystique as a legendary heroine was expanded and embellished. Expedient comparisons were sought in Boudica's name, derived from the Celtic word bouda, ${ }^{52}$ which means 'victory', in the feminine, Victoria. Thus, in essence, whilst Boudica became Victoria, Victoria embodied Boudica. Tennyson, as the Poet Laureate in 1860, wrote a commanding and difficult work, basing the metre on that of the Roman poet Catullus, entitled Boudicea, in which finally she is the main voice (Collingridge [2006]2012:348). The balance of power is switched in this poem because Boudica is no longer the restrained civilised monarch, but is terrifying in her hatred of the foreign invaders, describing herself as a 'lover of liberty' and a freedom fighter for her people:

Me the wife of rich Prasutagus, me the lover of liberty,

Me they seized and me they tortured, me they lash'd and humiliated. (Tennyson 1859 Boadicea)

In this poem, Boudica is portrayed as savage and barbaric:

Take the hoary Roman head and shatter it, hold it abominable Cut the Roman boy to pieces in his lust and voluptuousness, Lash the maiden into swooning, me they lash'd and humiliated, Chop the breasts from off the mother, dash the brains of the little one out,

Up my Britons, on my chariot, on my chargers, trample them under us. (Tennyson 1859 Boadicea no line nos)

Words such as 'lash'd', 'chopped the breasts', 'shatter' and 'dashed the brains' show uncontrolled violence and passion, 52. In modern welsh, this is buddug. 
and Johnson (2012:118) considers her in Tennyson's poem to be one of the great child killers of popular history, whom she likens to Medea. Boudica becomes associated with Old Testament prophets espousing justice, being battle driven and blood thirsty. Fortunately, although considered something of a tour de force, the work has, according to Webster (1978:14), sunk into well-deserved oblivion. I would argue that this graphic speech is an echo of the furious Boudica from Dio and the barbaric actions he described are shown as being spoken by Boudica herself. This allows her to be used as an ideological device for separating justified war from savagery, an important issue in times of British imperial expansion. This version has transformed Boudica as she bears little resemblance to either the person she had been portrayed as or the heroic figure she was to become. Here there is little resemblance to the reigning monarch, Victoria. Yet, as Victorian colonialism expanded, the figure of Boudica became the stand-in for the power of the monarch and becoming ideologically melded to the figure of Britannia.

The far-flung colonies became a terrifying and intimidating place for the female settler, and Collingridge ([2006]2012:369) sees this as being the moment of Boudica's reaffirmation, as her more warlike attributes had now been taken over by Britannia, as the moral and military guardian of the empire. Once again a metamorphosis took place; Boudica, still the fighter, was now tempered, and, accompanied by her children, used as images to reassure the women of Britain and their families that they were safe in the hands of the empire, no matter where they were. She was now redefined and related to as a mother and a widow whilst being presented as safe from sexual contamination. She now became the working man's female version of John Bull and became a public metaphor. In conjunction with Britannia, the two icons represented all facets of what was seen as desirable, grit and culture, passion and patriotism and above all they were all things to all women (Collingridge [2006]2012:370). Boudica became rooted in the domestic sphere as a genuine British heroine, a passionate nationalist as she was transformed into a national icon through poems, plays and pageants that emphasised the unfolding of her drama, the strength of her rhetoric and as always that primal powerful mix of sex and death. Hingley sees in effect an 'imperial cult of Boadicea' as she was transformed to create a historical ancestry for the British national pedigree and imperial greatness (Hingley \& Unwin [2005]2006:159). Although Victoria died (1901) whilst Britain was engaged in the AngloBoer War, her spirit along with that of Boudica and Britannia, the patron guardian warrior queens of the empire, was used to bolster the country's confidence and patriotic fervour. These warrior queens and other patriotic heroes such as the Kings Arthur and Alfred, medieval knights and kings joined together in a range of works of fiction and children's history books in celebration of national heroes, an important source of inspiration for late Victorian and early Edwardian children. ${ }^{53}$ It was at this time, 1902, that the most famous

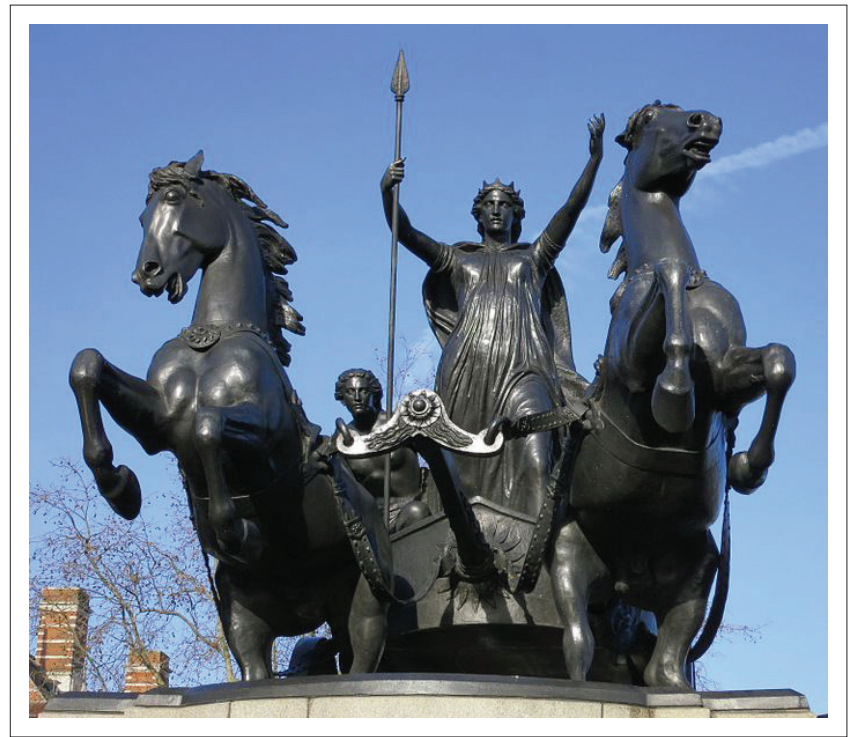

Source: Walter, P., 2013, 'Boudica statue, Westminster', viewed 05 September 2019, from https://www.flickr.com/photos/paulwalter/8433726848/

FIGURE 1: Thornycroft's statue: Boadicea and Her Daughters (1902) Westminister.

piece of work representing her was commissioned, the Thomas Thornycroft bronze (Figure 1).

The massive statue of Boudica and her daughters in her war chariot was set in place on the Embankment adjacent to Westminster Bridge, providing a symbolic defence for the House of Commons and the approach to London. Today this is still considered a memento of the empire, of Victoria and the ever-evolving symbolism of a 2000-year old unknown widow of a minor client ruler of Rome who became an international icon. The use of her image in social and political debate established her place and importance in representations of nation and that of modern women and this monument by Thornycroft has probably become the most widely known and ultimate embodiment of Boudica as the confident rebel commander.

The iconological ideologised figure of imperialistic Boadicea is standing erect and victorious with one arm raised to the skies as though she were addressing her people from a scythe-wheeled chariot. No longer is she subservient or a secondary figure; she is commanding, fierce and proud as she directs the horses onwards. There is no doubt that she is female and that is no longer hidden as the folds of her flowing classical robes make her sexual and goddess-like, whilst the rearing stallions are symbolic of harnessed male power over which she is in control. Her maternal imperialism, another facet of Boudica's iconography that emerged under Victoria, is represented through her daughters sheltering behind her in the chariot. The chariot itself represents her willingness to strive forward and act decisively and this in turn permits the ideological representation of imperialistic expansionism. The Thornycroft statue also reflects the reverential attitude that the British people now have for her, as she stands defiant as a powerful barbarian warrior ready to protect the seat of British government from all-comers and intimate defeat for 
those who attempt to overcome the Britons. She stands as an image imprinted in the minds of the majority of the British people, one that can create an emotive patriotic stir as she is cast in the role of a leader of her nation defending against allcomers, all the while occupying a mythic and elemental space. Even today, it is a site for protest; Tom Holland (2016) in his Op-ed sees it as a marker for 'Euroscepticism' that captured the 'spirit of Brexit' which reopens debate on the subject of Britain and domination by continental Europe.

Yet this is not the final Boudica. Since the British Empire passed, she has been appropriated by artists, folklorists and performers, causing her to move through more paradigm shifts, become less of a barbaric figure and more a figurehead of opposition to dominant forces and a means of centralising national identity (Hingley \& Unwin [2005]2006:213). The first of these appropriations was initiated by the women's suffragette movement at the beginning of the 20th century (Johnson 2012:126). Boudica was adopted as an early champion of women's heroic potential and achievement and her scythed chariot wheels became part of the emblem of the suffrage movement: the Women's Social and Political Union (WSPU) (Johnson 2012:137).

\section{Conclusion}

I argue that the use of Boudica suited the purpose of the Suffragette movement as it encompassed the necessary characteristics of female power, warrior-like qualities and agency. Seen as the embodiment of the rebel leader who fought for her people, a recognisable fighting spirit with a complexity of roles (mother, queen, rebel and warrior), she was easily identifiable with and became not only the 'mother' of the nation and symbol of the empire but also one of universal female suffrage. ${ }^{54}$ More recently, the warlike Boudica was used as a comparison to Margaret Thatcher and in fact she was likened to 'a bargain basement Boadicea' by Denis Healey (MacDonald 1988:69).

Writers, playwrights, poets and historians have all subjectively portrayed a Boudica conforming to the different ideological requirements of the time periods in which they lived. I have argued that she can be seen as a symbol and construct of the eras in which she was written about or artistically rendered from antiquity through to the present day. Some of these writers, I have demonstrated, used her figure for an individualised expression of political and private emotions, opinions, wants and desires. I have shown how Boudica took on a malleable identity and in her constant transformation was the symbol used to convey an understanding of the world at any given time whilst she

\footnotetext{
54.A march by the WSPU in May 1906 symbolically started from the Boudica statue on Westminster Bridge which made her monument a symbolic rallying point for the women's rights movement according to Sylvia Pankhurst. Other Boudican iconography was adopted by the movement; she was depicted on banners of theirs showing great women of the past (MacDonald 1988:55 quoting The Sunday Times) and in June 1911 women from the movement dressed as Boudica and other and in June 1911 women from the movement dressed as Boudica and other
famous heroines marched through the streets of London. In 1909, Cecily Hamilton's The Pageant opened in London, going on to tour in the country featuring great women in history such as Victoria, Elizabeth I, Joan of Arc and naturally Boudica (Fraser 1988:100-101; Hingley \& Unwin 2006:175-176).
}

also acted as the means of transmitting a political message..$^{55}$ Once the layers of bias, elaboration and adaptation have been stripped away from the Boudica story, it is possible to assess the quality of the historical writings on her and consider if any of these were able to stand outside the social and political concerns of their times. My assessment has attempted to argue that there is no doubt that once her image was resurrected from total obscurity, partly as a result of the reign of other powerful women, she was appropriated and transformed to serve a variety of ideological causes in different eras of British history. This dichotomy of interpretation has rendered her a chameleon, sometimes a villain and sometimes a heroine, but it is doubtful that she will ever lose her appeal for those who seek to unravel the legend of Boudica and her place in the British imagination. Ultimately, Boudica has triumphed, emerging as a seductively real heroine, an icon of popular British public nationalistic appeal, immortalised in bronze, driving her war chariot in defence of the Houses of Parliament. I have demonstrated that, invented and reinvented through the medium of pen, brush, chisel and celluloid, her legend remains one of a virago, a leader of a native uprising which could have radically altered British history had it proved successful.

\section{Acknowledgements Competing interests}

The author declares that she has no financial or personal relationships which may have inappropriately influenced her in writing this article.

\section{Author's contributions}

I declare that I am the sole author of this research article.

\section{Funding information}

This research received no specific grant from any funding agency in the public, commercial or not-for-profit sectors.

\section{Data availability statement}

Data sharing is not applicable to this article as no new data were created or analysed in this study.

\section{Disclaimer}

The views and opinions expressed in this article are those of the author and do not necessary reflect the official policy or position of any affiliated agency of the author.

\section{References}

Aske, T., 1588, Elizabetha Triumphans, Thomas Orwin, London

Barthes, R., 2013, Mythologies: The complete edition in a new translation, transl. R. Howard \& A. Lavers, Hill and Wang, New York.

Black, E.W., 2001, 'The first century historians of Roman Britain', Oxford Journal of Archaeology 20(4), 415-428. https://doi.org/10.1111/1468-0092.00145

55.It is important to remember that Tacitus himself is not a primary source for 1 st century history. Like Dio, he was using earlier written material, which is no longer extant. 
Bloom, C., 2010, Violent London: 2000 years of riots, rebels and revolts, Springer, Basingstoke.

Bouillet, M.N. \& Chasang, A. (eds.), 1878, Jean Xiphilin, Dictionnaire Universel d'histoire et de géographie, Hachette, Paris.

Braund, D., 1996, Ruling Roman Britain: Kings, queens, governors and emperors from Julius Caesar to Agricola, Routledge, London.

Carey, E.T., 1925, Dio, Cassius: Dio's Roman History, GB Putnam, London.

Collingridge, V., [2006] 2012, Boudica, Ebury Publishing, London.

Cowper, W., 1803, Poems. T.Bentley, London.

Dudley, D. \& Webster, G. 1962, The rebellion of Boudicca, Routledge, London.

Eggert, K., 2015, Showing like a queen: Female authority and literary experiment in Spenser, Shakespeare, and Milton, University of Pennsylvania Press, Philadelphia, PA.

Fletcher, J., 1979, 'Bonduca', in F. Bowers (ed.), The dramatic works in the Beaumont and Fletcher Canon, vol. 4, Cambridge University Press, Cambridge.

Fraser, A., 1988, The warrior queens: Boudicea's chariot, Weidenfield \& Nicholson, London.

Frénée-Hutchins, S., 2009, 'The cultural and ideological significance of representation of Boudica during the reigns of Elizabeth 1 and James 1', thesis, University of Exeter, University of Orleans.

Frénée-Hutchins, S., 2016, Boudica's Odyssey in early modern England, Routledge, London.

Grant, M.T., 1996, Tacitus: The annals of Imperial Rome, Penguin, London.

Graves, R.T., 2003, Suetonius: The twelve Caesars, Penguin, London.

Greenblatt, S., 1980, Renaissance self-fashioning, University of Chicago Press, London.

Hamilton, A.C., 2014, Spenser: The Faerie Queene, 2nd edn., Routledge, Abingdon, Oxon.

Hingley, R., 2000, Roman officers and English gentlemen: The imperial origins of Roman archaeology, Routledge, London.

Hingley, R. \& Unwin, C., [2005] 2006, Boudica: Iron age warrior, Hambledon Continuum, London.

Holland, T., 2016, 'When the Barbarous Brits first quit Europe', New York Times, 29 May.

Jeffries, S., 2004, 'Return of the queen', Guardian, viewed 20 August 2019, from https://www.theguardian.com/film/2004/jun/30/features.stuartjeffries.

Johnson, M., 2012, Boudicca, Bristol Classical Press, London.

Lawson, S., 2013, 'Nationalism and biographical transformation: The case of Boudicca', Humanities Research 19(1), 101-119. https://doi.org/10.22459/ HR.XIX.01.2013.06
MacDonald, S., 1988, 'Boadicea: Warrior, mother and myth', in S. MacDonald, P. Holden \& $\mathrm{S}$. Ardener (eds.), Images of women in peace and war: Cross-cultural and historical perspectives, pp. 40-61, University of Wisconsin Press, Madison, WI.

MacDougal, G., 1982, Racial myths in English history: Trojans, Teutons, and AngloSaxons, University Press of New England, Hanover, $\mathrm{NH}$.

Masson, S., 2002, 'The mirror of honour and love: A woman's view of chivalry', Quadrant 46(11), 56-59.

Matza, A., 2010, Historical commentaries, poetry and plays, Xlibris Corp, Bloomington, IN

McKerrow, R.B. (ed.), 1958, The works of Thomas Nashe, Oxford University Press, Oxford.

Mikalachki, J., 1998, The legacy of Boudicca: Gender and nation in early modern England, Routledge, London.

Neale, J.E., 1957, Queen Elizabeth I, Doubleday Anchor, New York.

Pearse, R., 2003, 'Gildas, De Excidio Britanniae: The ruin of Britain', Homepage of Tertullian, viewed 13 August 2019, from https://www.tertullian.org/fathers/ gildas_02_ruin_of_britain.htm.

Richmond, L.A., 1954, 'Queen Cartimandua', The Journal of Roman Studies 44(1-2), 43-52. https://doi.org/10.2307/297554

Rives, J.B., 2010, Tacitus: Agricola and Germania, Penguin, London.

Samuel, R., 1990, 'Grand narratives', Oxford Journals: History Workshop 29(1), 120-133.

Santoro L'Hoir, F., 1994, 'Tacitus and women's usurpation of power', The Classical World 88(1), 5-25. https://doi.org/10.2307/4351613

Sealey, P.R., 2004, The Boudican revolt against Rome, Shire Publications, Buckinghamshire, London.

Thompson, E.A., 1979, 'Gildas and the history of Britain', Britannia: Society for the Promotion of Roman Studies 10, 203-226. https://doi.org/10.2307/526057

Trow, M.J., 2003, Boudicca: The warrior queen, Sutton Publishing, Stroud.

Vance, N., 1997, The Victorians and ancient Rome, Blackwell, Oxford.

Walker, J.M., 2004, The Elizabeth icon: 1603-2003, Palgrave Macmillan, Houndmills.

Walter, P., 2013, 'Boudica statue, Westminster', viewed 05 September 2019, from https://www.flickr.com/photos/paulwalter/8433726848/.

Webster, G., 1978, Boudica: The British revolt against Rome AD60, Batsford, London. Williams, C.D., 2009, Boudica and her stories, University of Delaware Press, Newark, NJ.

Wright, C.T., 1946, 'The Elizabethan female worthies', Studies in Philology 43(4), 628-643.

Yuval-Davis, N., 1993, 'Gender and nation', Ethnic and Racial Studies 16(4), 621-632. https://doi.org/10.1080/01419870.1993.9993800 